\title{
THE EFFECT OF GINGER RHIZOMES (Curcuma xanthorriza Roxb.) TOWARDS THE NUMBER OF OVARIAN FOLLICLES OF FEMALE MICE (Mus musculus) EXPOSED TO MONOSODIUM GLUTAMAT (MSG)
}

\author{
Meilina Ratna Dianti \\ Department of Pharmacy Faculty of Medicine and Health Sciences Universitas Islam Negeri \\ Maulana Malik Ibrahim Malang \\ *Corresponding author: meilina_rd@yahoo.com
}

\begin{abstract}
Monosodium Glutamat activates an axis ablation in arcuate nucleus hypothalamus which happens to possibly initiate malfunctions in Hipothalamic Pituitary Adrenal axis. Yet, it is known that hypothalamus produces Gonadotropin Releasing Hormone which is able to stimulate the secretion of Gonadotropin Follicle Stimulating Hormon and Luteinizing Hormone from the anterior pituitary gland. These two hormones, however, are essentials for the development of gonad and during the cycles of oogenesis. Hence, any malfunctions resided in the human's hypothalamus can possibly put endocrine gland into troubles, such as reproduction hormones which affect the workings of gonad. Therefore, the extract of Temulawak is promoted to be the attempt to resolve the issue for its antioxidant properties. Temulawak extract contains antioxidant, properties for as much as $87.01 \mathrm{ppm}$, according to Rosidi research's result, analyzing the Temulawak's potentials. The amount of antioxidant found Temulawak extract is categorized as active and applicable as natural antioxidant source. However, this research adopts true experimental post-test only control group design. It includes 5 (five) groups of female mice as which are K1 (CMC), K2 (CMC+MSG), P1 (MSG+0.4 mg Temulawak extract), P2 (MSG+0.8 MG Temulawak extract), P3 (MSG+1.2 mg Temulawak extract). In addition, the mice's ovaries are removed to be subsequently tested using Hematoxillin-Eosin and the ovaries' follicles quantity is observed and counted. The data is analyzed using One Way ANOVA. The research finally comes with a result showing that there are not any significant differences discovered from the ovaries' follicles quantity from the five tested groups $(p>0.05)$. Therefore, it is implied that Temulawak extract does not provide any influential results to the house mice's ovaries' follicles quantity which has been exposed to $M S G$.
\end{abstract}

Keywords: Monosodium Glutamate (MSG), Temulawak (Curcuma xanthorriza Roxb.), Ovarian follicles quantity

\section{INTRODUCTION}

In this modern era, the use of MSG (Monosodium Glutamate) is increasing among the people as a flavor enhancer that makes food taste delicious on food (Pavlovic et al., 2009). The main factors are the information technology and many culinary travel whish changing lifestyles that make things faster and easier. In addition, the bustle of society itself which ultimately depend on the material processed food and fast food whish were easily available both in traditional markets and supermarkets.

MSG capacity in the world has been growing rapidly in recent years. Almost all food production using MSG as a flavor enhancer. MSG capacities are mostly found in Asia which accounts for about $91 \%$ of the production of MSG in the world in 2009. The International 
Headache Society (IHS) in 2010 reported that besides China, Indonesia is the main country that produced MSG in Asia which is expected to rise during 2009-2014. Based on data from the Health Research 2007, MSG is consumed by $77.8 \%$ of the population in Indonesia.

Based on the research results, consumes excessive MSG has a detrimental effect on health. After many years of use appear unpleasant effects are numbness and heart palpitations, nausea, headache, later known as "Chinese Restaurant Syndrome" (Sand, 2005). But in some animal studies prove that MSG does not have an adverse influence that the US Food and Drug Giving (FDA) stating that MSG is safe when consumed in quantity.

Using MSG in adults is safe to consume as much $3 \mathrm{gr} /$ day, while a teaspoon on average contain 4-6 grams of MSG and this can negatively affect later (Walter, 2000). Although MSG consumption for daily cooking is not that much, its still a dangerous because people are unaware of the levels of MSG used by culinary entrepreneurs in fast food. Consuming excessive MSG in the long term will have an impact on health, including reproductive health in both men and women (Das and Ghoah, 2011).

MSG causes ablation axis of the arcuate nucleus of the hypothalamus that can disrupt the function of hypothalamic pituitary adrenal (HPA) axis. The hypothalamus secretes gonadotropin-releasing hormone $(\mathrm{GnRH})$, which stimulates to spending Gonadotropin hormone Follicle Stimulating Hormone (FSH) and luteinizing hormone ( $\mathrm{LH}$ ) from the anterior pituitary. Both of these hormone necessary for male and female gonads development and of great importance to the process of spermatogenesis and oogenesis. Disruption of the hypothalamic function resulting in disruption of endocrine functions, including reproductive hormone that also affect gonadal function (Camihort, 2004).

Provision of MSG in mice (mus musculus) strain female Japanese influence FSH levels decrease significantly on female mice and also lowering LH levels even though doesn't significant (Maidawilis, 2010). In female mice, FSH and LH work to stimulate the development, maturation and ovulation in the ovaries. The decrease FSH and LH blood will certainly hamper the process of development and maturation of the ovarian follicle.

Megawati et al (2005) showed that giving of MSG in the rat (rattus norvegicus L) cause structural damage histological ovarian which discharge of granulosa cells from the basal lamina, there are many gaps between granulosa cells, releasing of follicle cells and into antrum, tissue damage into puzzles and egg cells degenerate. In quantitative terms, the provision of MSG in the rat did not affect significantly the number of primary follicles but can caused a significant reduction in the number of secondary follicle, tertiary follicle, the corpus luteum and cause an increase of follicle atresia.

By normal levels of hormone $17 \beta$-estradiol produced is highly dependent on the follicles in the ovaries which are necessary for ovulation, if normal follicle development takes place it will produce in normal hormone levels as well. Conversely, if during the process of follicular development is interrupted, then the follicle becomes atretik which would affect the levels of hormone estrogen is formed. It really depends on the amount of disruption that occurred during the process of follicular development (Andria, 2012). MSG also result in the removal of the oocytes in the ovaries effects in adult mice which exposed with high doses of MSG and contribute as a cause of infertility (Eweka, 2011).

Kalsum, et al (2010) reported infertility arising from the state of oxidative stress caused MSG, characterized by the formation of free radicals in the form of ROS. ROS damage the hypothalamus and ovaries because it has glutamate receptor over activation due to increased $\mathrm{Ca} 2+$ so as to cause cell death. This led to the development of ovarian follicles and $17 \beta$-estradiol levels decreased due to free radicals (Gill and Pillido 2008; Duan et al, 2007).

Siregar (2009) reported that the formation of free radicals in the body will be resisted by the body by increasing the production of glutathione, which is an antioxidant. This is in line with research Sukandar (2006), reported that the effects of free radicals in the body will 
be neutralized by antioxidants which are formed by the body itself and supplements from the outside through the meal, drinks and medicines such as vitamin $\mathrm{C}$, vitamin $\mathrm{E}$, and others. Hashem et al, 2012 reported that MSG as neurotoxin changes in the brain and atrocity decrease in the cerebral cortex in rats albino and vitamin $\mathrm{C}$ supplement shown to protect these changes. Giving combination of vitamin $\mathrm{E}$ and vitamin $\mathrm{C}$ is more effective than just one vitamin A (Sulistyowati, 2006).

Wild Ginger has active compound curcumin (Koller, 2008). Curcumin has antiinflammatory effect as, where curcumin inhibits cyclooxygenase-2 (COX-2), lipooxygenase (LOX), and inducible nitric oxide syntheses (iNOS). COX-2, LOX, iNOS is an important enzyme that mediates the inflammatory process (\& Sudheer Menon, 2007). (Anand, et al., 2008) (WHO, 2007). COX-2 plays a role in converting arachidonic acid to prostaglandins (PGS), thus indirectly, curcumin can inhibit the synthesis of PGS involved in the process of peptic ulcer and hypertension, renal (Subbaramiah, et al., 1996). Kawori et al, states that the granting of curcumin diet significantly inhibits phospholipids A2 in the intestinal mucosa, arachidonic acid is released from phospholipids, change the activity of COX and LOX, as well as alter the levels of PGS (Kawamori, Rao, Seibert, \& Reddy, 1998). Meanwhile, the active compound in turmeric essential oil which has been reported to contain a compound cynnamyl tiglate $(\mathrm{C} 14 \mathrm{H} 16 \mathrm{O} 2)$, eucalyptol $(\mathrm{C} 10 \mathrm{H} 18 \mathrm{O})$, methyl pinene $(\mathrm{C} 11 \mathrm{H} 18 \mathrm{O})$ and bicyclo 3.3.1-EN9 non-2-ol $(\mathrm{C} 9 \mathrm{H} 14 \mathrm{O})$ is suspected substances that can actively inhibit the release of IL1- $\beta$ and TNF- $\alpha$ in joint inflammation (Solfaine, Munawarman, Conservation, Agustina, \& Salasia, 2001).

Curcumin is also known can protect biological membranes against damage due to peroxidation. Lipid peroxidation reaction causes the formation of free radicals that cause damage to the cell membrane. Curcumin will inhibit the peroxidation process by binding with free radicals curcumin (Wright, 2002). It has been reported that the mechanism of the antioxidant curcumin data through: (1) bind free radicals, (2) interacting with a cascade of oxidative and prevent product cascade such, (3) reduce the amount of oxygen involved in the reaction of oxidative, (4) inhibits oxidative enzymes such as cytochrome $\mathrm{P}-450$, and (5) eliminate oxidative materials consisting of metal ions such as iron (Ravindran, Babu, and Sivaraman, 2007).

Based on getting free use of MSG and research results about the effects that can cause oxidative stress has been proved that MSG affects the reproductive organs and hormones that inhibit the growth of ovarian follicles and the levels of 17 $\beta$-estradiol, this study was conducted to determine the effect ginger rhizome (Curcuma xanthoriza Roxb.) various doses of the number of ovarian follicles female mice (Mus musculus) which exposed MSG.

\section{METHOD}

\section{Research design}

This study uses a true experimental design because there is a treatment and control group randomized to the type of post test only control group where the testing is done after the intervention. Interventions performed in mice (Mus musculus) females that meet the criteria. Groups of treated mice were given Monosodium Glutamate (MSG) and extract of ginger rhizome (Curcuma xanthoriza Roxb. Roxb. Roxb. Roxb.). This study investigates the potential of ginger rhizome extract (Curcuma xanthoriza Roxb. Roxb.) varying doses of the number of ovarian follicles in mice (Mus musculus) were exposed MSG. 


\section{Procedure}

Mice were weighed according to the inclusion criteria to obtain the desired subject. Test animals used in research are mice (Mus musculus) 1-2-month-old female weighing 18-35 grams. Selected animal models of mice, because mice (Mus musculus) have an important role for scientific purposes because adaptation is good, cheap, easy to get, easy maintenance, a relatively short lifespan, reproductive cycle resembles mammalian and high reproductive capability.

Mice were acclimatized or left to adapt for 7 days before being treated with the purpose of conditioning the animal with a laboratory atmosphere. Mice were placed in a cage made of plastic buckets (size $20 \mathrm{~cm} \times 30 \mathrm{~cm}$ x $40 \mathrm{~cm}$ ) lined with thick husk 0.5 to $1 \mathrm{~cm}$ and the hull cleaned and replaced every two weeks. Cage covered with a material made of wire. Mice used in the study, before being treated firstly be shaped pellet feed supply. Feed ratshaped pellets composition consists of protein, fat and crude fiber and calcium and phosphorus, previously mixed evenly with water so that the consistency was not hard. Mice were also given in the form of drinking boiled water. Standard feed and drink provided $a d$ libitum. The atmosphere in the stable conditioned enclosure with adequate ventilation and the room temperature is maintained between $27^{\circ} \mathrm{C}-28^{\circ} \mathrm{C}$ according to the physiological needs of mice.

In this study, mice as test animals were divided randomly into 5 groups, with two control groups and three treatment groups. The control group was divided into two, control 1 and control 2 respectively denoted by $\mathrm{K} 1$ and $\mathrm{K} 2$, while the treatment group were divided into 3 groups I, II, and III, respectively denoted by P1, P2, and P3. Mice were as much as 5 individuals as the control group 1 (K1) with the standard feed, 5 rats as a control group 2 with standard feed and exposed MSG for 42 days, 5 mice are used as the group treated with standard feed and exposed MSG $19.6 \mathrm{mg}$ and given $0.4 \mathrm{mg}$ of ginger extract for 42 days for P1, 5 mice treated with standard feed and exposed MSG $19.6 \mathrm{mg}$ and $0.8 \mathrm{mg}$ of ginger extract for 42 days for P2, 5 mice treated with standard feed and exposed MSG $19.6 \mathrm{mg}$ and $1.2 \mathrm{mg}$ of ginger extract for 42 days to $\mathrm{P} 3$.

In the treated mice, female mice exposed before with MSG, it first has to do the weighing of the mice using a ohaus scale. Once weighed, the new can determine how many doses required by the mice with a standard dose of MSG is $19.6 \mathrm{mg} / 20 \mathrm{gr}$ BB. Mice exposed MSG 1 times giving at the same time each day before being giving the extract of ginger rhizome (Curcuma xanthoriza Roxb. Roxb. Roxb.). MSG is given on K2, P1, P2, and P3. MSG was dissolved in $1 \mathrm{ml}$ of distilled water, given orally using a naso gastric tube (NGT)and performed at the Laboratory of Animal Physiology Faculty of Biology Department Saintek UIN Maliki.

The extract of ginger rhizome (Curcuma xanthoriza Roxb. Roxb. Roxb.) performed at the same time each day after the giving of MSG in mice and given as much 1x Award. Extract of ginger rhizome (Curcuma xanthoriza Roxb. Roxb. Roxb.) at a dose of $0.4 \mathrm{mg}, 0.8 \mathrm{mg}$, and $1.2 \mathrm{mg}$ dissolved in 1\% CMC (Ketut, 2009) and giving orally to the mice using a naso gastric tube. There are 5 steps of extract of ginger rhizome (Curcuma xanthoriza Roxb. Roxb. Roxb.), namely: (1) Incorporate ginger rhizome extract (Curcuma xanthoriza Roxb. Roxb. Roxb.) diluted with $1 \%$ CMC into a $3 \mathrm{cc}$ syringe that had been installed naso gastric tube (NGT)at the edges; (2) Holding the neck of mice with slow and cautious; (3) Insert the naso gastric tube (NGT) into the mouths of mice through the ceiling slowly up to the pharynx and esophagus; (4) Then push the ginger rhizome extract solution (Curcuma xanthoriza Roxb. Roxb. Roxb.) already in the syringe into the esophagus so that solvent extract of ginger rhizome (Curcuma xanthoriza Roxb. Roxb. Roxb.) can reach the stomach; (5) Removing rats and return to the fold. 
Sampling cytology performed after acclimatization and giving treatment for 42 days in mice. Before the mice were terminated, then the vaginal smear examination to determine the estrous cycle in mice at estrus phase because in this phase of the ovarian follicle development occurs. Samples were obtained by taking vaginal epithelial tissue of mice. Tools and materials to be prepared include: swab, cover glass, glass object, methylene blue, alcohol, $\mathrm{NaCl} 0.9 \%$ and microscopes. First of all, swab moistened with $0.9 \% \mathrm{NaCl}$ is then inserted into the vagina of mice at $45 \%$ and wiped as much as $1-2$ times a round $360^{\circ}$. The results of reviews of the swab is applied to the object glass and dried. Mixture reviews that have been drained put in absolute alcohol solution for fixation for 3 minutes and then removed and washed using water and dried. Selanjutya preparations incorporated into a solution methylene blue for 15 minutes, then removed and rinsed with running water, then dried, then observed the morphology of epithelial cells under a microscope with 400x magnification (Nadjamudin et al, 2010; Nalley et al, 2011).

The organ harvesting mice were performed after 42 days of treatment and the mice from the vagina reviews are in phase with pins proestrus vaginal epithelial cell nuclei (Wahyuni, 2005). The stage surgery mice were as follows: (a) Preparing the equipment and materials used for minor surgical comprising: tweezers, scissors, board surgical, pin, filter paper, chloroform, formalin $10 \%$ and the bottles are closed to place the organs of mice , as well as forms for recording; (B) Mice were terminated by entering the enclosed space containing cotton drops of chloroform ether, then closed tightly and wait a few minutes until the mice were completely dead (no moving anymore), make sure that the ether does not spread throughout the laboratory; (C) dead mice placed on the bed board with stomach facing up (fixed well). Mice were placed on a pedestal by using a pin board that is plugged into the palms of the hands and feet; (D) The abdominal wall surgery (if necessary shave located on the abdomen of mice that will be operated) by using tweezers and scissors carefully by an incision in the midline proceed to the left and right side on the top side and the bottom and the diaphragm is opened; (E) The ovaries are taken carefully by cutting right at the isthmus of the fallopian tubes left and right; (F) The ovary is cleaned of all ligaments are attached and subsequent ovarian cleaned of blood $(0.9 \% \mathrm{NaCl})$ organ drained using filter paper with one pressure; $(\mathrm{G})$ Enter the ovary into the bottle containing the solution of $10 \%$ buffered formalin fixative soaked for 12-24 hours; (i) Organ ready to be sent for histology and made preparations for the HE staining then calculated the number of follicles for processing into preparations in Anatomical Pathology laboratory RSSA Poor; (K) The carcasses of mice was left and not used again, buried safely so there is no environmental pollution.

\section{RESULTS AND DISCUSSION}

Table 1. Number of Ovarian Follicles

\begin{tabular}{|c|l|c|c|c|c|c|}
\hline \multirow{2}{*}{ No } & \multirow{2}{*}{ FOLLICLE } & \multicolumn{5}{|c|}{ NUMBER OF FOLLICLES } \\
\cline { 3 - 7 } & & K1 & K2 & P1 & P2 & P3 \\
\hline 1 & Primary follicle & 4 & 3 & 3 & 8 & 2 \\
\hline 2 & Secondary follicles & 13 & 8 & 11 & 11 & 14 \\
\hline 3 & Tertiary follicles & 4 & 5 & 5 & 7 & 7 \\
\hline 4 & Follicles de graaf & 1 & 1 & 1 & 1 & 1 \\
\hline
\end{tabular}

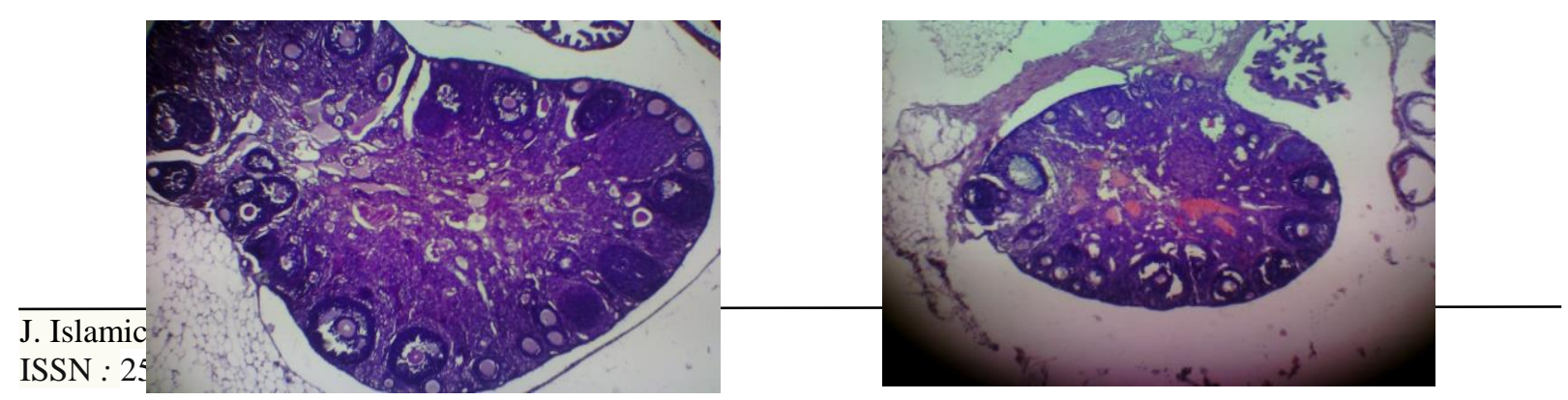




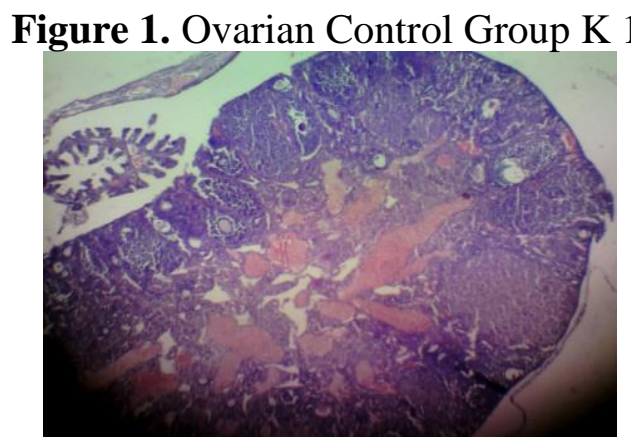

Figure 3. Ovarian Treatment Group P1
Figure 2. Ovarian Control Group K2

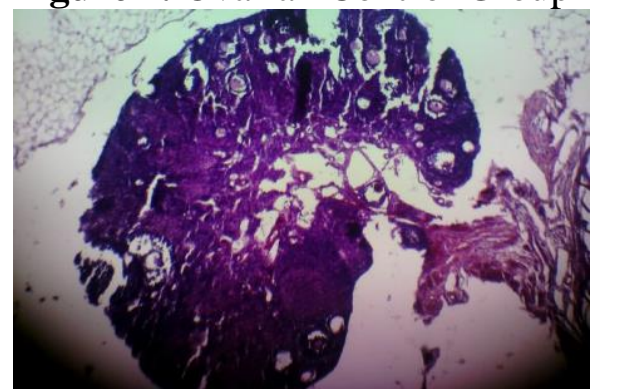

Figure 4. Ovarian Treatment Group P2

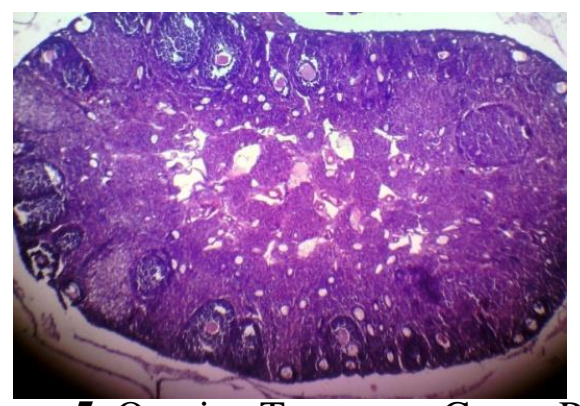

Figure 5. Ovarian Treatment Group P3

Based on the analysis using ANOVA, was obtained p-value of 0.842 , more than $\alpha=$ 0.05 , so that from this test it can be concluded that there is no significant effect of extract of ginger rhizome various doses of the number of ovarian follicles of female mice which exposed MSG.

This study reports the effect of ginger rhizome extract the number of ovarian follicles. Statistical analysis showed no effect of ginger rhizome extract the number of primary follicles, secondary, tertiary and de graaf. Total average pre antral follicles control and treatment groups did not differ significantly.

In the pre-antral stage, the primordial follicles up to the secondary follicle, the oocyte and follicle growth is regulated by paracrine factors intraovarian and did not influenced by the hormone gonadotropin. The paracrine factors that produced by the oocyte, granulosa cells and surrounding by the oocyte teca cells. This phase is characterized by three important processes: (1) collection of primordial follicles entering developing follicles; (2) developing oocyte and (3) an increase in FSH and LH receptors on granulosa cells and theca cells (Marco conti, et. $\mathrm{Al}, 2012)$.

Antral follicle development begins with the formation of antrum and granulosa cell differentiation to form cumulus cells / cumulus ooporus covering by primary oocytes and murals lining the walls of the follicle. At the cumulus cells, granulosa cells attached directly to the pellucida zona which is called corona radiata. The formation of antral follicle oocytes is to resume meiosis support (Conti and Chang, 2010; Kierszenbaum and Tres. 2012). In addition, antral stage also depends on FSH and LH. FSH receptor mRNA expression induced luteinizing hormone (Lhcgr) in mural cells, which would have required the follicle to respond to LH in triggering ovulation. The absence of RLH, follicles are disabling to grow up to the antral stage. While FSH is plays a role in the formation of antrum and preventing apoptosis. Under the influence of $\mathrm{LH}$, theca interna cells secrete the androstinedion, an androgen which is transferred to the granulosa cells through the basal lamina to produce testosterone. Bond 
FSH and its receptor enhances the activity of the enzyme aromatase that androstenedione is converted to estradiol (Conti and Chang, 2010; Kierszenbaum and Tres., 2012; Strauss III and Williams, 2014).

The number of antral follicles is used as one of the parameters that need to be examined ovarian reserve. The more follicles develop into early antral follicles, can lead to decreased ovarian reserve and increasing the occurrence of early menopause. According Bentzen, et al. (2012), the number of antral follicles affect the ovarian reserve size, low ovarian reserve is likely to have long-term effects that would shorten the duration of a woman's reproductive age.

Monosodium Glutamate (MSG) causes ablation of the arcuate nucleus of the hypothalamus axis so that it can disrupt the function of hypothalamic pituitary adrenal (HPA) axis. The hypothalamus secretes gonadotropin-releasing hormone $(\mathrm{GnRH})$, which stimulates spending Gonadotropin hormone Follicle Stimulating Hormone (FSH) and luteinizing hormone ( $\mathrm{LH})$ from the anterior pituitary. Both of these hormones, are necessary for male and female gonadal development and also importance for the process of spermatogenesis and oogenesis. Disruptions of the hypothalamic function can also causing disruption of endocrine functions, including reproductive hormone that also affect gonadal function (Camihort, 2004).

Megawati et al (2005) showed that giving of MSG in the rat (rattus norvegicus L) cause structural damage histological ovarian which discharge the granulosa cells from the basal lamina, there are many gaps between granulosa cells, the releasing follicle cells and get into antrum, tissue damage puzzles and egg cells degenerated. In quantitative terms, giving MSG to the rat did not affect significantly the number of primary follicles but caused a significant reduction in the number of secondary follicle, tertiary follicle, the corpus luteum and cause an increase of follicle atresia.

Several studies have shown that ginger rhizome extract has antioxidant content. Rosidi, et al (2014) in his research that analyzed the potential of ginger as an antioxidant concluded that ginger rhizome extract has antioxidant activity amounted to $87.01 \mathrm{ppm}$ which are classified as active, potentially as a natural antioxidant that is good. The active component responsible as antioxidants in the extract of ginger rhizome is curcumin, demetoksicurcumin, and bisdemetoksicurcumin (Masuda, 1992). Curcumin has an important force in the process of these antioxidants. The curcumin structure is consist of phenolic hydroxyl groups and beta diketone group. Phenolic hydroxyl group serves as a catcher of free radicals on the first phase of anti-oxidative mechanism. In the structure of curcumin are contained of two phenolic groups, so that the molecules of curcumin can counteract of two free radicals. Cluster beta diketone serves as a catcher of free radicals on the next phase (Rao, 1995).

Curcumin is also known can protect biological membranes against damage due to peroxidation. Lipid peroxidation reaction causes the formation of free radicals that cause damage to the cell membrane. Curcumin will inhibit the peroxidation process by binding with free radicals curcumin (Wright, 2002). It has been reported that the mechanism of the antioxidant curcumin data through: (1) bind free radicals, (2) interacting with a cascade of oxidative and prevent product of cascade, (3) reduce the amount of oxygen involved in the oxidative reaction, (4) inhibits oxidative enzymes such as cytochrome $\mathrm{P}-450$, and (5) eliminate oxidative materials consisting of metal ions such as iron (Ravindran, Babu, and Sivaraman, 2007).

Based getting free use of MSG and research results about the effects that can cause oxidative stress, that has been proved that MSG affects the reproductive organs and hormones and inhibit the growth of ovarian follicles and the levels of $17 \beta$-estradiol.

Karanth et al., (2001) in her study of the effects of antioxidants on mice concluded that antioxidants can stimulate spending gonadotropin ( $\mathrm{LH}$ and $\mathrm{FSH}$ ) from the anterior pituitary. 
Ruder et al., (2008) adds that antioxidants may help to protect the possibility of ovarian tissue from oxidative stress.

Siregar (2009) reported that the formation of free radicals in the body will be resisted by the body itself by increasing the production of glutathione, which is an antioxidant. This is in line with Sukandar's research (2006) which reported that the effects of free radicals in the body will be neutralized by antioxidants which are formed by the body itself and supplements from the outside through the meal, drinks and medicines such as vitamin $\mathrm{C}$, vitamin $\mathrm{E}$, and others. Hashem et al, 2012 reported that MSG as neurotoxic changes in the brain and astrocit decrease in the cerebral cortex in rats albino and vitamin $C$ supplement shown to protect these changes. Giving combination of vitamin $\mathrm{E}$ and vitamin $\mathrm{C}$ is more effective than just giving one vitamin A (Sulistyowati, 2006).

Studies on the effects of antioxidants on endometrial thickness has also been done by Wahyuni, et al., (2014) which the studies concluded that the antioxidant content in a combination of vitamins $\mathrm{C}$ and $\mathrm{E}$ can inhibit endometrial toxicity caused by giving of MSG orally through increased endometrial thickness ,

In this study, the extract of ginger is expected to have a function as an antioxidant as well as on the consumption of vitamin $\mathrm{C}$ as an antioxidant. In the result showed that there was no significant effect from the extract of ginger on the number of ovarian follicles in female mice which exposed MSG. This happens because of many factors. In the control group who were given exposure to MSG without given antioxidant and ginger extracts obtained profiles the number of ovarian follicles tend to decline if we compared with the control group which were only given a standard feed without being exposed to MSG and without being given a ginger extract. While the treatment group gained an increasing number of multiple follicles and also some reduction in the number of follicles obtained and there is a fixed number of follicles which stay in the same level, doesn't increase nor decrease. Hastati and Ariani (2008) explains that the decrease in endometrial thickness in the delivery of analog Curcumin may occur because of Curcumin causes hypoxia in the previous state caused by the mechanism of Curcumin as COX-2 inhibitors such as inhibition of proliferation of epithelial cells, inducing apoptosis and disrupt the function of angiogenesis resulting in hypoxia, causing a decrease in endometrial thickness. A significant decrease in the thickness of endometrial, may also affecting to the production of the ovarian follicle. Because of some cases of hypoxia in the reproductive organs will affecting hormonal processes in the reproductive organs and can cause ovarian follicles can not ripen so that the profile tends to decrease the number of follicles. Despite a decline in the average of ovarian follicle in the treatment group P1 and P2 in mice which exposed MSG, but the decrease was statistically not significant. 


\section{REFERENCES}

[1] Agarwal, A., and Prabakaran S.A. 2005. Oxidative Stress and Antioxidants in Male Infertility: a Difficult Balance, Iranis Journal of Reproductive Medicine, 3 (1): 1-8.

[2] Blachier, F. at al. 2009. Metabolism and Functions of Glutamate in The Epithelial Cells of The Small and Large Intestines, Am J Clin Nutr. 90 (suppl) : 814S-21S.

[3] Conn, P.J. 2003. Physiological Roles and Therapeutic Potential of Metabotropic Glutamate Receptors. Abstracts Ann N y Acad Sci 1003:12-21.

[4] Dewing, P., at al. 2007. Membrane Estrogen Receptor $\alpha$ Interactions with Metabotropic Glutamate Receptor 1a Modulate Female Sexual Receptivity in Rats, The Journal of Neuroscience. 27 (35): 9294-9300.

[5] Dumalska, I,. at al., 2008. Exitatory Effects of Pubertry Initiating Peptide Kisspeptin aand Group 1 Meabotropic Glutamate Receptor Agonists Differentiate Two Distinct Subpopulations of Gonadotropin Releasing Hormone Neurons, J. Neuroscience. 28 (32): 8003-8013.

[6] Foran, E. and Trooty, D. 2009. Glutamate Transporters and The Exitotoxic Path to Motor Neuron Degenaration in Amyotrophic Lateral Sklerosis, J. Antioxid Redox Signal. 11 (7): 1587-1602.

[7] Ganong, W. F., 2003. Review of Medical Physiology. Twenty First Edition. Mc Graw Hill. p. $425-429$.

[8] Gill, S., Barker M., and Pulido O., 2008. Neuroexitatory Targets in The Female Reproductive System of The Nonhuman Primate (Mecaca Fascicularis). J. Toxicologic Patholoy. 36:478.

[9] Gill, S., at al., 2007. Human Heart Glutamate Receptors Implications for Toxicology, Food Safety, and Drug Discovery. J Toxicologic Patholoy. 35:411

[10] Gill, S.S., and Pulido O.M., 2001. Glutamate Receptors in Peripheral Tissues: Current Knowledge, Future Research, and Implications for Toxicology , J. Toxicologic Pathology, 29:208

[11] Gill, S.S., Mueller R.W. Mcguire P.F., and Pulido O.M., 2009. Potential Target Sites in Peripheral Tissues for Exitatory Neurotransmission and Excitotoxity, J. Toxicologic Pathology. 28: 277

[12] Graham, T.E., at al., 2000. Glutamate Ingestion: The Plasma and Muscle Free Amino Acid Pools of Resting Humans. Am J Physiol Endocrinol Metab. 278: E83-E89.

[13] Gu, G., at al., 1999. Hormonal Regulation of Glutamate Receptor Gene Expression in the Anteroventral Periventricular Nucleus of The Hypotalamus, J. Neuroscience. 19 (8): 3213-3222.

[14] Halliwell, B., 2007. Free Radicals in Biology and Medicine. Fourth edition. Oxford University Press. Chapter 2 and chapter 3,p.42-72.

[15] Hanafiah, K.A. 2012. Rancangan Percobaan Teori dan Aplikasi. Edisi ketiga. Raja Grafindo Persada. Jakarta.

[16] Hawkins., r., 2009. The Blood Brain Barrier and Glutamate, Am J Clin Nutr. 90 (suppl): $867 \mathrm{~S}-74 \mathrm{~S}$.

[17] Hellen, W and Lynn. E. 2000. Oxidative Stress and Antioxidant, Influence On Health and Brain Aging. Departement of Nutrition and Dietetics, King's College London. UK.

[18] Ketut, M., at al., 2006. Pemberian Konsumsi Vitamin C dan E Peroral Memperbaiki Kerusakan Hepar Akibat Pajanan Rokok Kretek SubKronik. 24 (1) Fakultas Kedokteran Universitas Brawijaya Malang

[19]Lazar, L. 2012. The Role of Oxidative Stress in Female Reproduction and Pregnancy, Oxidative Stress and Disease. Ed Dr. Volodymyr Luschak. p. 313-336. 
[20]Loliger, J., 2000. Function and Importance of Glutamate for Savory Foods, The Journal of Nutrition. 130: 915S-920S.

[21] Maidawilis, 2010. Pengaruh Pemberian Monosodium Glutamat terhadap Kadar Follicle Stimulating Hormon Mencit (Mus musculus) Betina strain Jepang. Tesis Program Pascasarjana Universitas Andalas Padang.

[22] Marchondes, F.K., at al,. 2002. Estrous Cycle Staging, Braz J. Biol. 62(4a): 609-614.

[23] Meeker, R.B., at al,.1994 Glutamate Receptors in the Rat Hypothalamus and Pituitary. Abstracts Neurology. 134 (2): 621

[24]Megawati D., at al., 2005. Siklus Estrus dan Struktur Histologi Ovarium Tikus Putih (Rattus Novergicus L) Setelah Pemberian Monosodium Glutamat (MSG) Secara Oral, $J$. Biosmart 7 (1): 47-52.

[25] Micevych, P., Bondar G., Kuo J.,, 2010. Estrogen Actions on Neuroendocrine Glia, J. Neuroendocrinology. $91: 211-222$.

[26] Nadjamudin, Rusdin, at al., 2010. Penentuan siklus estrus pada kancil (Tragulus Javanicus) Berdasarkan Perubahan Sitologi Vagina. Jurnal Veteriner: 11: 81-86.

[27] Nicoletti, F., at al,. 2007. Metabotropic Glutamate Receptors: Beyond The Regulation of Synaptic Transmission, J. Psychoneuroendocrinology. Doi: 10.

[28] Niswender, C.M., and Conn P.J., 2010. Metabotropic Glutamate Receptors: Physiology, Pharmacology, and Desease, Annu Rev Phamacol Toxicol. 50:295-322.

[29] Pacheco, R., at al., 2006. Glutamate Release by Denditic Cells as a Novel Modulator of T Cell Activation, J. Immunology. 177:6695-6704.

[30]Padayatty, S.J., at al., 2003. Vitamin C as an Antioxidant: Evaluation of Its Role in Disease Prevention, J. American College of Nutrition. 22 (1): 18-35.

[31]Speroff, L., and Fritz M.A., 2005. Female Infertility. In: Clinical Gynaecologic Endocrinology and Infertility. Seventh edition. Lippincott Williams and Wilkins, Philadelphia, p. 1014-1019. 